\title{
Methodology effects on determining the energy concentration and the apparent total tract digestibility of components in diets fed to growing pigs
}

\author{
Chengfei Huang ${ }^{1}$, Ping Li', Xiaokang Ma', Neil William Jaworski ${ }^{3}$, Hans-Henrik Stein ${ }^{4}$, Changhua Lai', \\ Jinbiao Zhao ${ }^{1}$, and Shuai Zhang ${ }^{1, *}$
}

\footnotetext{
* Corresponding Author: Shuai Zhang Tel: +86-10-62731109, Fax: +86-10-62733688, E-mail: zhangshuai16@cau.edu.cn

1 State Key Laboratory of Animal Nutrition, College of Animal Science and Technology, China Agricultural University, Beijing 100193, China

2 Institute of Animal Science, Guangdong Academy of Agricultural Sciences, Guangzhou 510640, China

${ }^{3}$ Trouw Nutrition, Veerstraat 38, 5831 JN Boxmeer, The Netherlands

${ }^{4}$ Department of Animal Sciences, University of Illinois, Urbana, IL 61801, USA

ORCID

Shuai Zhang

https://orcid.org/0000-0001-5435-2640
}

Submitted Oct 16, 2017; Revised Dec 19, 2017; Accepted Jan 26, 2018
Objective: An experiment was conducted to investigate the effects of different diet formulations: F1 (Two complicated basal diets containing different crude protein levels plus tested feedstuff) vs F2 (A simple corn soybean meal [SBM] basal diet plus tested feedstuff) combined with total collection (TC) or chromic oxide $\left(\mathrm{Cr}_{2} \mathrm{O}_{3}\right)$ marker or acid-insoluble ash (AIA) marker method, and freeze-dry or oven-dry (OD) technique on estimation of nutrient digestibility in diets fed to growing pigs.

Methods: In F1, twelve barrows were allocated to two $6 \times 4$ Youden Squares. The treatment diets included a high protein basal (HPB) diet, a low protein basal (LPB) diet, a corn diet and a wheat bran (WB) diet formulated based on the HPB diet, and a SBM diet and a rapeseed meal (RSM) diet formulated based on the LPB diet. In F2, eight barrows were allocated to two $4 \times 4$ Latin Squares. The treatment diets included a corn basal diet, a SBM basal diet formulated based on the corn diet, and a WB diet and a RSM diet formulated based on the SBM diet.

Results: Concentration of digestible (DE) and metabolizable energy (ME), and the apparent total tract digestibility of gross energy, ash, neutral detergent fibre, and acid detergent fibre determined by $\mathrm{Cr}_{2} \mathrm{O}_{3}$ marker method were greater than those determined by TC and AIA marker methods in HPB, LPB, and RSM diets formulated by F1 and in corn diet formulated by F2 ( $\mathrm{p}<0.05)$. The DE values in WB and both DE and ME values in SBM and RSM estimated using F1 were greater than those estimated using F2 $(\mathrm{p}<0.05)$.

Conclusion: From the accuracy aspect, the AIA marker or TC method combined with OD technique is recommended for determining the energy concentration and nutrient digestibility of components in diets fed to growing pigs.

Keywords: Barrows; Digestibility; Drying Methods; Index Marker; Total Collection

\section{INTRODUCTION}

The digestibility of components in feed is usually determined either by direct or indirect methods. Direct method was typically used when evaluating cereals such as corn, wheat, barley, and sorghum [1-3]. Some feedstuffs containing high crude protein (CP) such as soybean meal (SBM), rapeseed meal (RSM), and fish meal, or high fibre feedstuffs such as wheat bran (WB) or corn distillers dried grains with solubles cannot be fed alone to pigs for a long period, so indirect methods such as regression or difference methods were used $[4,5]$. The fundamental assumption of the difference method is that there is no interaction between the digestibility values of components in the test ingredient and the basal diet. This assumption might not be true. Several studies have compared the effects of different basal diets on 
digestibility coefficients of various ingredients fed to pigs [68]. In Europe, formulation of swine diet was normally more complicated than that in China or North America, which mainly based on corn and SBM. The constituent of basal diets might have effect on the results of difference method used to evaluate feedstuffs [5]. The digestibility of component in feed can be determined by total collection (TC) or index marker (IM) methods when using either direct or indirect methods. The TC method was relatively precise but labor intensive [9]. External markers such as chromic oxide $\left(\mathrm{Cr}_{2} \mathrm{O}_{3}\right)$ and titanium dioxide [10-12], and internal markers such as acid-insoluble ash (AIA) and lignin were usually used in IM methods $[13,14]$. However, results evaluated by TC vs IM methods or regression vs direct methods varied substantially among different experiments $[11,15]$. In addition, the drying techniques such as oven-drying vs freeze-drying had different effects on the nitrogen and energy concentration in excreta $[16,17]$. Therefore, the primary objective of this study was to compare two different procedures of diet formulation: F1 (Two complicated basal diets containing different $\mathrm{CP}$ levels plus tested feedstuff) vs F2 (A simple corn SBM basal diet plus tested feedstuff) combinated with three approaches to estimating nutrient digestibility of diets: TC method, $\mathrm{Cr}_{2} \mathrm{O}_{3}$ marker method, and AIA marker method. Moreover, the effects of two drying techniques (oven-dry [OD] vs freeze-dry [FD]) for feces samples were compared on en- ergy and CP digestibility of feeds fed to growing pigs.

\section{MATERIALS AND METHODS}

The protocol for all animal procedures were approved by the Institutional Animal Care and Use Committee at China Agricultural University, Beijing, China.

\section{Experimental design and diets}

Formulation one: Twelve crossbred barrows (Duroc $\times$ Landrace $\times$ Large white) with an initial body weight (BW) of $35.0 \pm 2.1 \mathrm{~kg}$ were used. All pigs were allocated to two $6 \times 4$ Youden square design with 4 periods and 6 diets, and 2 replicated pigs per diet in each period. Each period contained 7 days of diet adaptation and followed by 5 days of feces collection. The treatment diets (Table 1) included a high protein basal (HPB) diet, a low protein basal (LPB) diet, and four experimental diets formulated by substituting $40.0 \%$ corn or $25.0 \% \mathrm{WB}$ at the expense of HPB diet, or $30.0 \%$ SBM or RSM at the expense of LPB diet, respectively.

Formulation two: Eight crossbred barrows (Duroc $\times$ Landrace $\times$ Large white) with an initial BW of $38.5 \pm 2.9 \mathrm{~kg}$ were used in this study. All pigs were allocated to two $4 \times 4$ Latin square design with 4 periods and 4 diets, and 2 replicated pigs per diet in each period. Each period contained 7 days of diet adaptation and followed by 5 days of feces collection. The treatment

Table 1. Ingredient composition of the experimental diets (\% as fed basis)

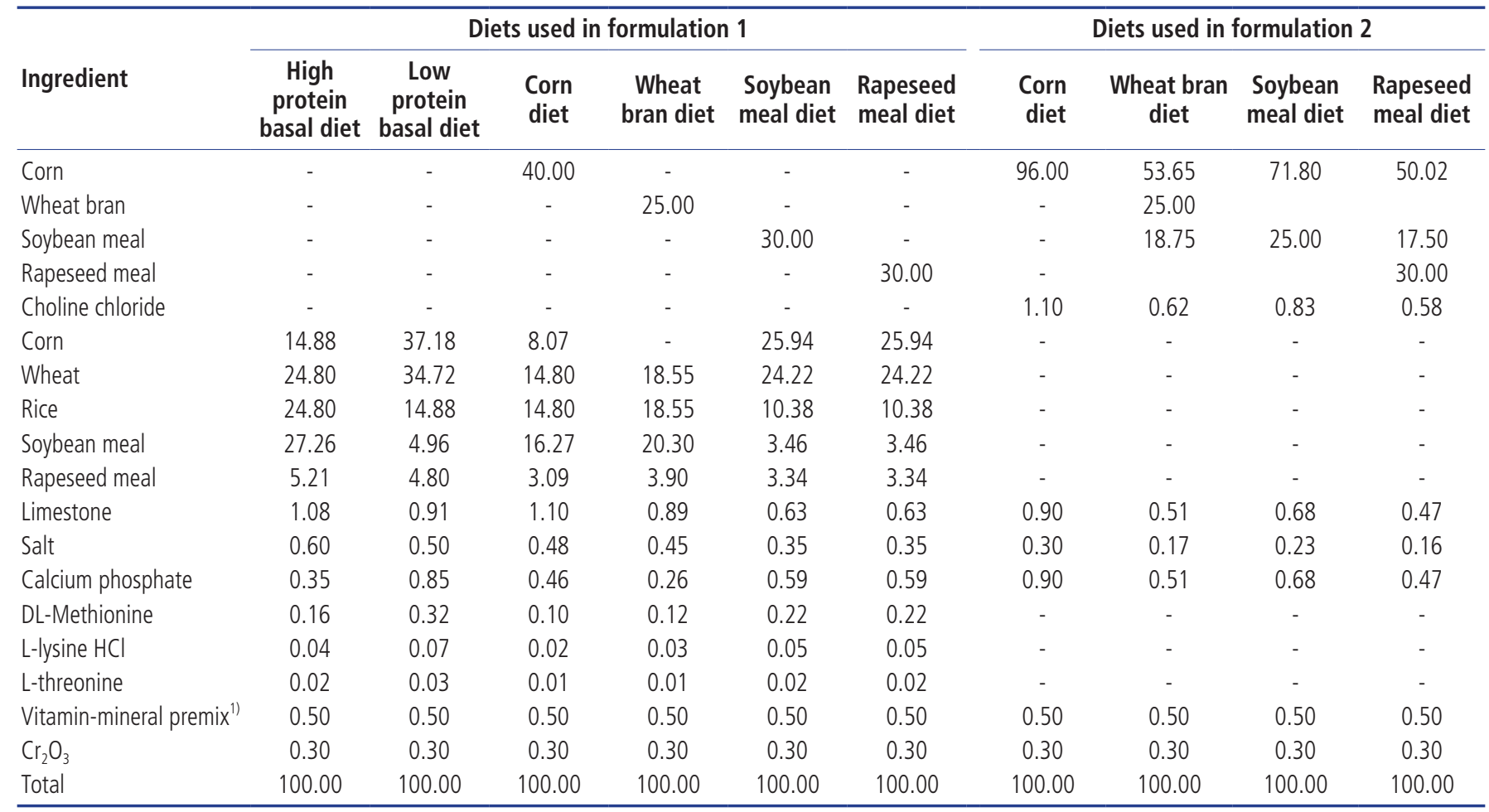

\footnotetext{
1) Premix provided the following quantities of vitamins and microminerals per $\mathrm{kg}$ of complete diet: vitamin $\mathrm{A}, 5,512 \mathrm{IU}$; vitamin $\mathrm{D}_{3}, 2,200 \mathrm{IU}$; vitamin $\mathrm{E}, 64 \mathrm{IU}$; vitamin $\mathrm{K}_{3}$, 2.2 mg; vitamin $B_{12}, 27.6 \mu$ g; riboflavin, 5.5 mg; pantothenic acid, 13.8 mg; niacin, 30.3 mg; choline chloride, 551 mg; Mn, 40 mg; Fe, 100 mg; Zn, 100 mg; Cu, 100 mg; I, 0.3 $\mathrm{mg} ; \mathrm{Se}, 0.3 \mathrm{mg}$.
} 
diets (Table 1) included a corn basal diet, a SBM basal diet formulated by substituting $25.0 \%$ SBM at expense of the corn diet, and two test diets formulated by substituting $25.0 \% \mathrm{WB}$ or $30.0 \%$ RSM at the expense of the SBM diet.

Chromic oxide $\left(\mathrm{Cr}_{2} \mathrm{O}_{3}\right)$ was added in each experimental diet at $0.3 \%$. Vitamins and minerals were supplemented in all diets to meet or exceed the nutrient requirements of pigs according to NRC [18]. The analyzed composition of experimental diets and tested ingredients were presented in Table 2 and 3 , respectively.

\section{Animals feeding and housing}

The experiment was conducted in the Swine and Poultry Nutrition Research Center of the National Feed Engineering Technology Research Center (Chengde, China). Pigs were placed in individual metabolic crates $(1.4 \times 0.7 \times 0.6 \mathrm{~m})$ that were equipped with a self-feeder, a nipple waterer, and slatted floors to allow for the total, but separate, collection of feces and urine. For the F1 formulation, feed intake of pigs was restricted to 2.2 times of the energy requirement for body maintenance: Daily feed allowance $(\mathrm{kg} / \mathrm{d})=\left(419 \times 0.7 \times 3.2 \times \mathrm{BW}^{0.75}, \mathrm{KJ} / \mathrm{d}\right) /$ $\mathrm{NE}_{\text {feed }}(\mathrm{KJ} / \mathrm{kg})$; For the $\mathrm{F} 2$ formulation, daily feed was offered to pigs at $3 \%$ of each pigs BW. All feeds for both formulations were provided to pigs each day in 2 equal meals at 0800 and 1600. All pigs had free access to water throughout the experiment.

\section{Sample collection}

Feed consumption was recorded daily and treatment diets were fed for 12 days. The initial 7 days were considered as the adaptation period to the diet, and urine and feces collection were completed during the following 5 days. A time-based collection method was used [8]. Each feces and urine collection day was $24 \mathrm{~h}$ of full collection with no marker used to signify beginning or end of collection. Stainless steel collection
Table 3. Analyzed composition of corn, wheat bran, soybean meal, and rapeseed meal ( $\%$ as fed basis) ${ }^{1)}$

\begin{tabular}{lcccc}
\hline & \multicolumn{4}{c}{ Ingredient } \\
\cline { 2 - 5 } Item & Corn & $\begin{array}{c}\text { Wheat } \\
\text { bran }\end{array}$ & $\begin{array}{c}\text { Soybean } \\
\text { meal }\end{array}$ & $\begin{array}{c}\text { Rapeseed } \\
\text { meal }\end{array}$ \\
\hline Dry matter & 91.20 & 92.10 & 92.60 & 92.00 \\
Gross energy (MJ/kg) & 16.39 & 17.21 & 17.74 & 17.46 \\
Crude protein & 8.30 & 18.30 & 46.40 & 37.20 \\
Ash & 1.00 & 4.90 & 6.00 & 6.70 \\
Crude fibre & 2.00 & 9.00 & 4.00 & 12.00 \\
Ether extract & 3.00 & 3.40 & 0.90 & 1.90 \\
Neutral detergent fibre & 8.70 & 39.00 & 12.80 & 27.00 \\
Acid detergent fibre & 1.50 & 9.80 & 5.30 & 17.50 \\
Starch & 64.70 & 19.70 & 8.70 & 8.30 \\
\hline
\end{tabular}

${ }^{1)}$ Analysis conducted in duplicates.

trays and urine collection buckets containing $50 \mathrm{~mL}$ of $6 \mathrm{~N}$ $\mathrm{HCl}$ were put under the metabolism cages at 1600 on day 8 and removed at 1600 on day 13 . Feces samples and $20 \%$ of the collected urine were stored at $-20^{\circ} \mathrm{C}$ immediately after collections. At the end of the experiment, feces and urine samples were thawed and mixed separately within pig and diet, and subsampled for analysis.

\section{Drying techniques for feces}

Two drying techniques included FD and OD for feces were conducted at the same time. Half of the total feces collected in 5 days were dried in an oven for $72 \mathrm{~h}$ at $65^{\circ} \mathrm{C}$, and remained in the oven for one more day at $25^{\circ} \mathrm{C}$. The remaining half of the fecal samples were transferred into vacuum tubes and frozen in a freeze dryer, where the samples were cooled to $-110^{\circ} \mathrm{C}$ under a vacuum pressure of $\leq 100 \mu \mathrm{m}$ for $48 \mathrm{~h}$. Freezedried feces also remained in the freeze dryer for one more day at $25^{\circ} \mathrm{C}$ (total of $72 \mathrm{~h}$ of freeze drying). Both oven-dried and freeze-dried feces were ground through a 1-mm screen

Table 2. Analyzed composition of the experimental diets (\% as fed basis) ${ }^{11}$

\begin{tabular}{|c|c|c|c|c|c|c|c|c|c|c|}
\hline \multirow[b]{2}{*}{ Item } & \multicolumn{6}{|c|}{ Diets used in formulation 1} & \multicolumn{4}{|c|}{ Diets used in formulation 2} \\
\hline & $\begin{array}{c}\text { High } \\
\text { protein } \\
\text { basal diet }\end{array}$ & $\begin{array}{c}\text { Low } \\
\text { protein } \\
\text { basal diet }\end{array}$ & $\begin{array}{l}\text { Corn } \\
\text { diet }\end{array}$ & $\begin{array}{l}\text { Wheat } \\
\text { bran diet }\end{array}$ & $\begin{array}{l}\text { Soybean } \\
\text { meal diet }\end{array}$ & $\begin{array}{l}\text { Rapeseed } \\
\text { meal diet }\end{array}$ & $\begin{array}{l}\text { Corn } \\
\text { diet }\end{array}$ & $\begin{array}{c}\text { Wheat bran } \\
\text { diet }\end{array}$ & $\begin{array}{l}\text { Soybean } \\
\text { meal diet }\end{array}$ & $\begin{array}{l}\text { Rapeseed } \\
\text { meal diet }\end{array}$ \\
\hline Dry matter & 91.00 & 90.00 & 89.00 & 91.00 & 90.00 & 90.00 & 90.00 & 90.00 & 90.00 & 91.00 \\
\hline Gross energy (MJ/kg) & 15.96 & 15.82 & 15.71 & 16.20 & 16.20 & 16.16 & 15.51 & 15.90 & 15.65 & 16.01 \\
\hline Crude protein & 21.10 & 14.70 & 16.20 & 19.90 & 22.60 & 20.00 & 8.80 & 18.50 & 18.90 & 19.90 \\
\hline Ash & 5.40 & 4.40 & 4.40 & 5.00 & 4.60 & 5.40 & 4.40 & 6.10 & 5.60 & 6.30 \\
\hline Crude fibre & 2.40 & 2.40 & 2.40 & 3.70 & 2.60 & 4.90 & 1.70 & 4.00 & 2.30 & 5.40 \\
\hline Ether extract & 1.50 & 1.90 & 1.90 & 2.00 & 1.70 & 2.00 & 1.40 & 2.30 & 1.40 & 2.50 \\
\hline Neutral detergent fibre & 8.70 & 10.10 & 10.40 & 13.40 & 9.40 & 14.90 & 8.70 & 15.50 & 9.50 & 16.90 \\
\hline Acid detergent fibre & 3.30 & 3.50 & 4.10 & 4.70 & 3.60 & 6.70 & 2.20 & 4.80 & 3.20 & 7.60 \\
\hline Starch & 43.60 & 51.60 & 51.20 & 38.80 & 39.10 & 38.40 & 60.90 & 38.50 & 43.70 & 36.50 \\
\hline Acid-insoluble ash & 0.60 & 0.60 & 0.60 & 0.60 & 0.50 & 0.80 & 1.30 & 1.00 & 1.20 & 1.40 \\
\hline
\end{tabular}

${ }^{1)}$ Analysis conducted in duplicates. 
for chemical analysis.

\section{Sample analysis}

Feed and feces samples were analyzed for gross energy (GE) via an adiabatic oxygen bomb calorimeter (Parr Instruments, Moline, IL, USA), dry matter (DM) (method 930.15; AOAC 2006) [19], CP (method 984.13; AOAC 2006) [19], ether extract (EE) [20], and ash (method 942.05; AOAC 2006) [19]. Crude fibre (CF), neutral detergent fibre (NDF), and acid detergent fibre $(\mathrm{ADF})$ were determined using fiber bags and fiber analyzer equipment (Fibre Analyzer, Ankom Technology, Macedon, NY, USA) following the procedure described by Van Soest et al [21]. Starch concentration in feed and GE in urine were analyzed using methods described by Zhang et al [22]. Determination of $\mathrm{Cr}_{2} \mathrm{O}_{3}$ in feed and feces were completed as described by Chen et al [23]. The AIA concentration of feeds and feces were determined using the method of Atkinson et al [24].

\section{Calculations}

For the TC method, digestibility and metabolizability of feed components were calculated according to the following equations [5]:

$$
\begin{aligned}
& \text { Digestibility (\%) }=\left[\left(\mathrm{C}_{\text {input }}-\mathrm{C}_{\text {output }}\right) / \mathrm{C}_{\text {input }}\right] \times 100 \text {, and } \\
& \text { Metabolizability (\%) }=\left[\left(\mathrm{C}_{\text {input }}-\mathrm{C}_{\text {output }}-\mathrm{C}_{\text {urine }}\right) / \mathrm{C}_{\text {input }}\right] \times 100
\end{aligned}
$$

Where $\mathrm{C}_{\text {input }} \mathrm{C}_{\text {output }}$ and $\mathrm{C}_{\text {urine }}$ are the amount of component ingested, and the amount of component voided via the feces and via the urine, respectively.

For the IM methods, digestibility of feed components were calculated using the following equation [5]:

$$
\begin{aligned}
& \text { Digestibility (\%) } \\
& =100-\left[\left(\mathrm{CI}_{\text {input }} \times \mathrm{CC}_{\text {output }}\right) /\left(\mathrm{CC}_{\text {input }} \times \mathrm{CI}_{\text {output }}\right) \times 100\right]
\end{aligned}
$$

Where $\mathrm{CI}_{\text {input }}$ and $\mathrm{CI}_{\text {output }}$ are the concentration of index compound in feed and feces, respectively; $\mathrm{CC}_{\text {input }}$ and $\mathrm{CC}_{\text {output }}$ are the concentration of component in feed and feces, respectively.

The digestibility of components in the test ingredients was determined using the difference method and is calculated according to the following formula described by Kong and Adeola [5]. We assumed that there was no interaction between the digestibility values of components in the test ingredient and those in the basal diet. The calculation was as follows:

$$
\mathrm{D}_{\mathrm{ti}}=\left[\mathrm{D}_{\mathrm{td}}-\left(\mathrm{D}_{\mathrm{bd}} \times \mathrm{P}_{\mathrm{bd}}\right)\right] / \mathrm{P}_{\mathrm{ti}}
$$

In which $\mathrm{D}_{\mathrm{bd}}, \mathrm{D}_{\mathrm{td}}$, and $\mathrm{D}_{\mathrm{ti}}$ are the digestibility (\%) of the component in the basal diet, test diets, and test ingredient, respectively, and $\mathrm{P}_{b d}$ and $\mathrm{P}_{t \mathrm{i}}$ are the proportional contribution of the component by the basal diet and test ingredient to the test diet, respectively.

The recovery rate of marker was calculated as described by Jagger et al [25].

\section{Statistical analyses}

Data were checked for normality and outliers were detected and removed using the UNIVARIATE procedure of SAS (SAS Inst. Inc., Cary, NC, USA). To test the effects of different methods within each diet, data were analyzed by one-way analysis of variance (ANOVA) using the general linear model (GLM) procedure of SAS, with pig as the experimental unit and the experimental methods of TC vs AIA vs $\mathrm{Cr}_{2} \mathrm{O}_{3}$ or OD vs FD was the only main effect included in the model. To test the effects of different methods within each ingredient, data were analyzed by two-way ANOVA using the GLM procedure of SAS, and the statistical model included the main effect of method of F1 vs F2, the main effect of method of TC vs AIA vs $\mathrm{Cr}_{2} \mathrm{O}_{3}$, and their interaction effect. Since all interaction effects were not significant, only the main effects were shown in the results. Treatment means were calculated using the LSMEANS statement, and were separated using the TukeyKramer test. Significant differences were declared at $\mathrm{p}<0.05$.

\section{RESULTS AND DISCUSSION}

Recovery rate of chromic oxide and acid-insoluble ash The recovery rate of AIA ranged from 0.87 to 1.05 among the ten experimental diets. A wide range of 0.78 to 1.17 for the recovery rate of $\mathrm{Cr}_{2} \mathrm{O}_{3}$ was observed in the ten experimental diets (Table 4). There were no significant differences between the recovery rate of $\mathrm{Cr}_{2} \mathrm{O}_{3}$ and AIA in the experimental diets except that a greater recovery rate of $\mathrm{Cr}_{2} \mathrm{O}_{3}$ was observed in LPB diet or SBM diet formulated using F1 formulation ( $\mathrm{p}<$ $0.05)$. The big variation in the recovery rate of $\mathrm{Cr}_{2} \mathrm{O}_{3}$ was in agreement with the previously reports $[10,26]$. The good recovery rate of AIA indicated that AIA can be used as a good marker for calculation of nutrient digestibility.

\section{Effect of formulations combined with TC or IM} methods on determining energy concentration and nutrient digestibility in diets

Concentration of digestible (DE) and metabolizable energy (ME), and the apparent total tract digestibility (ATTD) of GE, ash, NDF, and ADF in HPB, LPB, and RSM diet in F1 formulation and corn diet in $\mathrm{F} 2$ formulation determined by the AIA marker method were lower than those determined by the $\mathrm{Cr}_{2} \mathrm{O}_{3}$ marker method $(\mathrm{p}<0.05)$, and no differences were observed between the results gained by the AIA marker method and those by the TC method (Table 5, 6). The same pattern was shown for the ATTD of CP in the LPB diet. The lower 
Table 4. The recovery rate of chromic oxide and acid-insoluble ash in ten experimental diets 1 )

\begin{tabular}{|c|c|c|c|c|c|c|c|c|c|c|}
\hline \multirow[b]{2}{*}{ Item } & \multicolumn{6}{|c|}{ Diets used in formulation 1} & \multicolumn{4}{|c|}{ Diets used in formulation 2} \\
\hline & $\begin{array}{c}\text { High } \\
\text { protein } \\
\text { basal diet }\end{array}$ & $\begin{array}{c}\text { Low } \\
\text { protein } \\
\text { basal diet }\end{array}$ & Corn diet & $\begin{array}{l}\text { Wheat } \\
\text { bran diet }\end{array}$ & $\begin{array}{l}\text { Soybean } \\
\text { meal diet }\end{array}$ & $\begin{array}{l}\text { Rapeseed } \\
\text { meal diet }\end{array}$ & Corn diet & $\begin{array}{l}\text { Wheat } \\
\text { bran diet }\end{array}$ & $\begin{array}{l}\text { Soybean } \\
\text { meal diet }\end{array}$ & $\begin{array}{l}\text { Rapeseed } \\
\text { meal diet }\end{array}$ \\
\hline Acid-insoluble ash marker method & 0.89 & 0.97 & 0.91 & 0.95 & 0.87 & 0.95 & 0.94 & 1.05 & 0.96 & 0.93 \\
\hline $\mathrm{Cr}_{2} \mathrm{O}_{3}$ marker method & 1.02 & 1.13 & 0.78 & 1.00 & 1.09 & 0.97 & 1.02 & 0.99 & 1.17 & 0.98 \\
\hline SEM & 0.09 & 0.04 & 0.05 & 0.04 & 0.05 & 0.08 & 0.11 & 0.10 & 0.09 & 0.10 \\
\hline p-value & NS & * & NS & NS & $* *$ & NS & NS & NS & NS & NS \\
\hline
\end{tabular}

SEM, standard error of means; NS, non-significant.

1) Data were calculated by using the freeze-dried feces.

${ }^{*} p<0.05,{ }^{* *} p<0.01$.

DE and ME values or ATTD of nutrients in feeds evaluated by the AIA marker method compared with the $\mathrm{Cr}_{2} \mathrm{O}_{3}$ marker method can be explained by the lower recovery rate of AIA marker. No significant differences were observed between the $\mathrm{DE}$ and ME values and ATTD of GE evaluated by the TC method and those by the $\mathrm{Cr}_{2} \mathrm{O}_{3}$ marker method in the HPB diet, but in LPB diet, the DE, ME, and the ATTD of GE determined by the $\mathrm{Cr}_{2} \mathrm{O}_{3}$ marker method were greater than those calculated by the TC method ( $\mathrm{p}<0.05)$. This may be mainly due to the high CP level in HPB diet. The dietary protein level was found to be negatively correlated with the ME/DE ratio $(\mathrm{r}=-0.956)$, indicating that protein level in diets had a profound effect on the ME obtainable from DE, and thus the conventional methods (e.g. the TC method) lead to underestimated energy content of high protein feeds [6]. In addition, the slightly greater (1.4\%) NDF level in the LPB diet compared with the HPB diet may influence the determined results, because fibre is the main factor that could affect the energy values of feed [27]. As for similar previous studies on methodology in evaluating swine diets, various results were reported. The aforementioned effects of calculation methods (TC vs IM methods) on dietary component digestibility were inconsis-

Table 5. Effects of different methods on digestible energy (DE), metabolizable energy (ME), and the apparent total tract digestibility (ATTD) of gross energy (GE) in experimental diets fed to growing pigs (\% as-fed basis) ${ }^{1)}$

\begin{tabular}{|c|c|c|c|c|c|c|c|c|c|c|c|}
\hline \multirow[b]{2}{*}{ Item } & \multirow[b]{2}{*}{ Method } & \multicolumn{6}{|c|}{ Diets used in formulation 1} & \multicolumn{4}{|c|}{ Diets used in formulation 2} \\
\hline & & $\begin{array}{c}\text { High } \\
\text { protein } \\
\text { basal diet }\end{array}$ & $\begin{array}{c}\text { Low } \\
\text { protein } \\
\text { basal diet }\end{array}$ & $\begin{array}{l}\text { Corn } \\
\text { diet }\end{array}$ & $\begin{array}{l}\text { Wheat } \\
\text { bran diet }\end{array}$ & $\begin{array}{l}\text { Soybean } \\
\text { meal diet }\end{array}$ & $\begin{array}{l}\text { Rapeseed } \\
\text { meal diet }\end{array}$ & $\begin{array}{l}\text { Corn } \\
\text { diet }\end{array}$ & $\begin{array}{l}\text { Wheat } \\
\text { bran diet }\end{array}$ & $\begin{array}{l}\text { Soybean } \\
\text { meal diet }\end{array}$ & $\begin{array}{l}\text { Rapeseed } \\
\text { meal diet }\end{array}$ \\
\hline \multirow{5}{*}{ DE $(\mathrm{MJ} / \mathrm{kg})$} & Total feces collection method & $14.58^{\mathrm{ab}}$ & $14.28^{b}$ & 14.24 & 13.92 & 14.74 & $13.71^{b}$ & $13.86^{b}$ & 13.13 & 14.07 & 13.18 \\
\hline & Acid-insoluble ash marker method & $14.48^{b}$ & $14.32^{b}$ & 14.16 & 13.92 & 14.90 & $13.71^{b}$ & $13.81^{b}$ & 13.38 & 14.04 & 13.09 \\
\hline & $\mathrm{Cr}_{2} \mathrm{O}_{3}$ marker method & $14.84^{\mathrm{a}}$ & $14.68^{\mathrm{a}}$ & 14.33 & 14.17 & 14.81 & $14.12^{\mathrm{a}}$ & $14.22^{\mathrm{a}}$ & 13.59 & 14.29 & 13.57 \\
\hline & SEM & 0.08 & 0.08 & 0.07 & 0.08 & 0.07 & 0.09 & 0.08 & 0.15 & 0.09 & 0.18 \\
\hline & p-value & * & ** & NS & NS & NS & ** & ** & NS & NS & NS \\
\hline \multirow[t]{5}{*}{$\mathrm{ME}(\mathrm{MJ} / \mathrm{kg})$} & Total feces collection method & $14.37^{\mathrm{ab}}$ & $14.01^{b}$ & 13.93 & 13.70 & 14.44 & $13.37^{b}$ & $13.68^{b}$ & 12.93 & 13.85 & 13.02 \\
\hline & Acid-insoluble ash marker method & $14.27^{b}$ & $14.06^{b}$ & 13.85 & 13.69 & 14.60 & $13.37^{b}$ & $13.62^{b}$ & 13.18 & 13.83 & 12.93 \\
\hline & $\mathrm{Cr}_{2} \mathrm{O}_{3}$ marker method & $14.62^{a}$ & $14.42^{\mathrm{a}}$ & 14.02 & 13.94 & 14.52 & $13.78^{\mathrm{a}}$ & $14.04^{\mathrm{a}}$ & 13.40 & 14.07 & 13.41 \\
\hline & SEM & 0.10 & 0.07 & 0.10 & 0.10 & 0.10 & 0.10 & 0.06 & 0.16 & 0.09 & 0.19 \\
\hline & p-value & * & $* *$ & NS & NS & NS & * & $* * *$ & NS & NS & NS \\
\hline \multirow[t]{5}{*}{$M E: D E$} & Total feces collection method & 98.5 & 98.1 & 97.8 & 98.4 & 98.0 & 97.5 & 98.7 & 98.5 & 98.5 & 98.8 \\
\hline & Acid-insoluble ash marker method & 98.5 & 98.1 & 97.8 & 98.4 & 98.0 & 97.6 & 98.7 & 98.5 & 98.5 & 98.8 \\
\hline & $\mathrm{Cr}_{2} \mathrm{O}_{3}$ marker method & 98.5 & 98.2 & 97.8 & 98.4 & 98.0 & 97.6 & 98.7 & 98.5 & 98.5 & 98.8 \\
\hline & SEM & 0.2 & 0.4 & 0.3 & 0.4 & 0.3 & 0.4 & 0.2 & 0.3 & 0.4 & 0.2 \\
\hline & p-value & NS & NS & NS & NS & NS & NS & NS & NS & NS & NS \\
\hline \multirow[t]{5}{*}{ ATTD of GE } & Total feces collection method & $91.4^{\mathrm{ab}}$ & $90.2^{b}$ & 90.6 & 85.9 & 91.0 & $84.8^{b}$ & $89.4^{b}$ & 82.6 & 89.9 & 82.3 \\
\hline & Acid-insoluble ash marker method & $90.7^{b}$ & $90.5^{b}$ & 90.1 & 85.9 & 92.0 & $84.8^{b}$ & $89.0^{b}$ & 84.2 & 89.7 & 81.7 \\
\hline & $\mathrm{Cr}_{2} \mathrm{O}_{3}$ marker method & $93.0^{\mathrm{a}}$ & $92.8^{\mathrm{a}}$ & 91.2 & 87.4 & 91.5 & $87.4^{\mathrm{a}}$ & $91.7^{\mathrm{a}}$ & 85.5 & 91.3 & 84.7 \\
\hline & SEM & 0.5 & 0.5 & 0.5 & 0.5 & 0.4 & 0.6 & 0.5 & 1.0 & 0.6 & 1.1 \\
\hline & p-value & * & ** & NS & NS & NS & ** & $* *$ & NS & NS & NS \\
\hline
\end{tabular}

SEM, standard error of means; NS, non-significant.

1) Data were calculated by using the freeze-dried feces.

${ }^{a-b}$ Means with different superscripts in each column differ significantly $(p<0.05)$; means are the least square means ( $\left.n=6 \sim 8\right)$.

${ }^{*} p<0.05,{ }^{* *} p<0.01,{ }^{* * *} p<0.001$. 
Table 6. Effects of different methods on the apparent total tract digestibility (ATTD) of nutrients in the experimental diets fed to growing pigs (\%)"

\begin{tabular}{|c|c|c|c|c|c|c|c|c|c|c|c|}
\hline \multirow[b]{2}{*}{ Item } & \multirow[b]{2}{*}{ Method } & \multicolumn{6}{|c|}{ Diets used in formulation 1} & \multicolumn{4}{|c|}{ Diets used in formulation 2} \\
\hline & & $\begin{array}{c}\text { High protein } \\
\text { basal diet }\end{array}$ & $\begin{array}{c}\text { Low protein } \\
\text { basal diet }\end{array}$ & Corn diet & $\begin{array}{c}\text { Wheat } \\
\text { bran diet }\end{array}$ & $\begin{array}{c}\text { Soybean } \\
\text { meal diet }\end{array}$ & $\begin{array}{l}\text { Rapeseed } \\
\text { meal diet }\end{array}$ & $\begin{array}{l}\text { Corn } \\
\text { diet }\end{array}$ & $\begin{array}{c}\text { Wheat } \\
\text { bran diet }\end{array}$ & $\begin{array}{c}\text { Soybean } \\
\text { meal diet }\end{array}$ & $\begin{array}{l}\text { Rapeseed } \\
\text { meal diet }\end{array}$ \\
\hline \multirow[t]{5}{*}{ ATTD of CP } & Total feces collection method & 90.5 & $89.1^{b}$ & 89.4 & 87.3 & 90.8 & 84.3 & 83.3 & 82.7 & 89.6 & 82.2 \\
\hline & Acid-insoluble ash marker method & 89.9 & $89.3^{b}$ & 88.8 & 87.3 & 91.7 & 84.2 & 82.7 & 84.1 & 89.2 & 81.7 \\
\hline & $\mathrm{Cr}_{2} \mathrm{O}_{3}$ marker method & 92.2 & $91.8^{\mathrm{a}}$ & 90.0 & 88.6 & 91.3 & 87.1 & 87.1 & 85.5 & 90.9 & 84.7 \\
\hline & SEM & 0.8 & 0.7 & 0.5 & 0.6 & 0.5 & 1.1 & 1.2 & 1.2 & 0.8 & 1.1 \\
\hline & p-value & NS & * & NS & NS & NS & NS & NS & NS & NS & NS \\
\hline \multirow[t]{5}{*}{ ATTD of ash } & Total feces collection method & $58.0^{\mathrm{b}}$ & $46.8^{b}$ & 52.5 & 45.2 & 52.0 & $41.0^{b}$ & $32.7^{\mathrm{b}}$ & 36.8 & 43.9 & 35.5 \\
\hline & Acid-insoluble ash marker method & $55.4^{b}$ & $48.1^{b}$ & 50.7 & 45.5 & 57.8 & $41.4^{b}$ & $32.3^{b}$ & 42.9 & 44.2 & 33.9 \\
\hline & $\mathrm{Cr}_{2} \mathrm{O}_{3}$ marker method & $66.3^{\mathrm{a}}$ & $60.7^{\mathrm{a}}$ & 56.1 & 51.0 & 55.0 & $50.4^{a}$ & $48.3^{\mathrm{a}}$ & 47.3 & 51.6 & 44.8 \\
\hline & SEM & 1.7 & 1.9 & 2.1 & 2.3 & 2.1 & 2.4 & 2.5 & 2.8 & 3.1 & 3.8 \\
\hline & $p$-value & $* * *$ & $* * *$ & NS & NS & NS & * & $* * *$ & NS & NS & NS \\
\hline \multirow[t]{5}{*}{ ATTD of CF } & Total feces collection method & 55.4 & $38.8^{\mathrm{b}}$ & 56.4 & 40.5 & $58.9^{b}$ & 41.1 & $36.5^{b}$ & 36.4 & 58.9 & 43.9 \\
\hline & Acid-insoluble ash marker method & 56.7 & $44.5^{\mathrm{ab}}$ & 57.8 & 46.6 & $66.5^{\mathrm{a}}$ & 45.4 & $40.0^{b}$ & 48.2 & 61.9 & 47.0 \\
\hline & $\mathrm{Cr}_{2} \mathrm{O}_{3}$ marker method & 64.4 & $54.5^{\mathrm{a}}$ & 59.3 & 47.1 & $62.0^{\mathrm{ab}}$ & 50.3 & $51.1^{\mathrm{a}}$ & 47.0 & 65.5 & 52.6 \\
\hline & SEM & 3.5 & 3.6 & 2.7 & 3.0 & 1.9 & 2.6 & 2.2 & 3.5 & 2.6 & 3.9 \\
\hline & $p$-value & NS & * & NS & NS & * & NS & ** & NS & NS & NS \\
\hline \multirow[t]{5}{*}{ ATTD of EE } & Total feces collection method & 75.1 & 73.2 & 76.6 & 68.5 & 76.2 & 68.4 & 59.6 & 66.5 & 62.1 & 74.0 \\
\hline & Acid-insoluble ash marker method & 71.9 & 74.1 & 74.4 & 67.3 & 78.1 & 68.2 & 51.5 & 67.0 & 59.5 & 70.9 \\
\hline & $\mathrm{Cr}_{2} \mathrm{O}_{3}$ marker method & 78.8 & 80.2 & 77.5 & 70.6 & 76.8 & 73.2 & 62.9 & 69.4 & 66.2 & 76.2 \\
\hline & SEM & 2.0 & 2.1 & 1.4 & 2.5 & 1.7 & 1.9 & 6.1 & 3.1 & 3.0 & 2.8 \\
\hline & $p$-value & NS & NS & NS & NS & NS & NS & NS & NS & NS & NS \\
\hline \multirow[t]{5}{*}{ ATTD of NDF } & Total feces collection method & $66.8^{\mathrm{ab}}$ & $55.4^{\mathrm{b}}$ & 65.8 & 56.5 & 66.4 & $54.2^{\mathrm{ab}}$ & $52.2^{\mathrm{ab}}$ & 50.3 & 57.2 & 53.5 \\
\hline & Acid-insoluble ash marker method & $62.5^{b}$ & $57.4^{b}$ & 62.4 & 54.3 & 69.4 & $53.7^{\mathrm{b}}$ & $42.3^{b}$ & 50.8 & 54.5 & 49.0 \\
\hline & $\mathrm{Cr}_{2} \mathrm{O}_{3}$ marker method & $71.7^{\mathrm{a}}$ & $67.8^{\mathrm{a}}$ & 66.6 & 59.1 & 67.4 & $60.9^{\mathrm{a}}$ & $56.0^{\mathrm{a}}$ & 54.1 & 61.3 & 58.1 \\
\hline & SEM & 1.9 & 1.9 & 1.7 & 1.9 & 2.1 & 2.0 & 3.3 & 3.3 & 2.9 & 2.6 \\
\hline & p-value & * & $* * *$ & NS & NS & NS & * & * & NS & NS & NS \\
\hline \multirow[t]{5}{*}{ ATTD of ADF } & Total feces collection method & $56.6^{\mathrm{ab}}$ & $38.1^{b}$ & 65.5 & 44.4 & 60.7 & $30.8^{\mathrm{ab}}$ & $32.8^{\mathrm{ab}}$ & 33.1 & 49.4 & 37.9 \\
\hline & Acid-insoluble ash marker method & $50.9^{b}$ & $41.0^{b}$ & 62.1 & 41.6 & 64.1 & $30.2^{\mathrm{b}}$ & $19.2^{b}$ & 33.6 & 46.2 & 32.0 \\
\hline & $\mathrm{Cr}_{2} \mathrm{O}_{3}$ marker method & $62.7^{\mathrm{a}}$ & $54.9^{\mathrm{a}}$ & 66.1 & 47.7 & 61.9 & $40.9^{\mathrm{a}}$ & $38.4^{a}$ & 38.3 & 54.3 & 43.3 \\
\hline & SEM & 2.6 & 3.6 & 2.0 & 2.4 & 2.0 & 3.0 & 4.5 & 5.1 & 3.8 & 4.6 \\
\hline & $p$-value & * & ** & NS & NS & NS & * & * & NS & NS & NS \\
\hline
\end{tabular}

CP, crude protein; SEM, standard error of means; NS, non-significant; CF, crude fibre; EE, ether extract, NDF, neutral detergent fibre; ADF, acid detergent fibre.

1) Data were calculated by using the freeze-dried feces.

${ }^{a-b}$ Means with different superscripts in each column differ significantly $(p<0.05)$; means are the least square means $(n=6 \sim 8)$.

${ }^{*} p<0.05,{ }^{* *} p<0.01,{ }^{* * *} p<0.001$.

tent with some previous results $[9,11,13]$, but in agreement with others which estimated DE and digestible nutrients using the TC and AIA marker methods $[8,11,28]$. A range of $97.5 \%$ to $98.8 \%$ for the ME/DE ratio was observed in the ten experimental diets in the current trial, which was close to the ratio of $96.0 \%$ in most complete feeds reported by Noblet [27]. The ATTD of GE, CP, ash, CF, EE, NDF, and ADF in ten experimental diets varied from $81.7 \%$ to $93.0 \%, 81.7 \%$ to $92.2 \%$, $32.3 \%$ to $66.3 \%, 36.4 \%$ to $66.5 \%, 51.5 \%$ to $80.2 \%, 42.3 \%$ to $71.7 \%$, and $19.2 \%$ to $66.1 \%$, respectively (Tables 5,6 ). The ATTD of GE falls into the normal range of $70 \%$ to $90 \%$ which was reported by Noblet [27].

A greater ATTD of CF calculated by the AIA marker method was detected compared with that determined by the TC method in SBM diet formulated by F1 ( $\mathrm{p}<0.05)$, but the ATTD of CF determined by the TC method was lower than that evaluated by the $\mathrm{Cr}_{2} \mathrm{O}_{3}$ marker method in LPB diet and corn diet formulated by F2 $(\mathrm{p}<0.05)$. Otherwise, no significant differences were observed on estimated energy contents and nutrient digestibility in each treatment diet between different determining methods.

Overall, considering the good recovery rate of AIA marker and the equal performance in estimating nutrient digestibility in diets between TC method and AIA marker method, the AIA is a reliable marker for measuring digestibility of components in swine feed.

\section{Effect of drying techniques on determining energy concentration and nutrient digestibility in diets}

The DE concentration in corn diet formulated by F1 was greater when determined using freeze-dried feces compared with that determined using oven-dried feces ( $<<0.05$, Table 7 ). A greater ATTD of GE $(p<0.05)$ evaluated using freeze-dried feces was observed in SBM diet and RSM diet formulated by F2 compared with that evaluated using oven-dried feces. These findings contradict with those of Jacobs et al [16], who reported no differences among drying techniques on estimating $\mathrm{DM}, \mathrm{GE}, \mathrm{N}, \mathrm{C}$, or $\mathrm{S}$ concentrations in pig feces. Some study 
Table 7. Effects of drying methods on digestible energy (DE), metabolizable energy (ME), and the apparent total tract digestibility (ATTD) of gross energy (GE) and crude protein (CP) in experimental diets fed to growing pigs (\% as fed basis) ${ }^{1)}$

\begin{tabular}{|c|c|c|c|c|c|c|c|c|c|c|c|}
\hline \multirow[b]{2}{*}{ Item } & \multirow[b]{2}{*}{ Dry method } & \multicolumn{6}{|c|}{ Diets used in formulation 1} & \multicolumn{4}{|c|}{ Diets used in formulation 2} \\
\hline & & $\begin{array}{l}\text { High protein } \\
\text { basal diet }\end{array}$ & $\begin{array}{l}\text { Low protein } \\
\text { basal diet }\end{array}$ & $\begin{array}{l}\text { Corn } \\
\text { diet }\end{array}$ & $\begin{array}{l}\text { Wheat } \\
\text { bran diet }\end{array}$ & $\begin{array}{l}\text { Soybean } \\
\text { meal diet }\end{array}$ & $\begin{array}{l}\text { Rapeseed } \\
\text { meal diet }\end{array}$ & Corn diet & $\begin{array}{c}\text { Wheat } \\
\text { bran diet }\end{array}$ & $\begin{array}{l}\text { Soybean } \\
\text { meal diet }\end{array}$ & $\begin{array}{l}\text { Rapeseed } \\
\text { meal diet }\end{array}$ \\
\hline \multirow[t]{4}{*}{$\mathrm{DE}(\mathrm{MJ} / \mathrm{kg})$} & Freeze-dry & 14.62 & 14.36 & 14.42 & 14.03 & 14.76 & 13.78 & 13.77 & 13.10 & 14.18 & 13.27 \\
\hline & Oven-dry & 14.58 & 14.28 & 14.24 & 13.92 & 14.74 & 13.71 & 13.86 & 13.13 & 14.07 & 13.18 \\
\hline & SEM & 0.10 & 0.06 & 0.05 & 0.07 & 0.04 & 0.12 & 0.09 & 0.12 & 0.09 & 0.17 \\
\hline & p-value & NS & NS & * & NS & NS & NS & NS & NS & NS & NS \\
\hline \multirow[t]{4}{*}{ ME (MJ/kg) } & Freeze-dry & 14.40 & 14.09 & 14.11 & 13.80 & 14.46 & 13.44 & 13.59 & 12.91 & 13.96 & 13.11 \\
\hline & Oven-dry & 14.37 & 14.01 & 13.93 & 13.70 & 14.44 & 13.37 & 13.68 & 12.93 & 13.85 & 13.02 \\
\hline & SEM & 0.12 & 0.07 & 0.09 & 0.10 & 0.07 & 0.12 & 0.07 & 0.11 & 0.10 & 0.16 \\
\hline & $p$-value & NS & NS & NS & NS & NS & NS & NS & NS & NS & NS \\
\hline \multirow[t]{4}{*}{$M E: D E$} & Freeze-dry & 98.5 & 98.1 & 97.8 & 98.4 & 98.0 & 97.6 & 98.7 & 98.5 & 98.5 & 98.8 \\
\hline & Oven-dry & 98.5 & 98.1 & 97.8 & 98.4 & 98.0 & 97.5 & 98.7 & 98.5 & 98.5 & 98.8 \\
\hline & SEM & 0.2 & 0.4 & 0.3 & 0.4 & 0.3 & 0.4 & 0.2 & 0.3 & 0.4 & 0.2 \\
\hline & $p$-value & NS & NS & NS & NS & NS & NS & NS & NS & NS & NS \\
\hline \multirow[t]{4}{*}{ ATTD of GE } & Freeze-dry & 93.8 & 91.5 & 89.1 & 85.3 & 92.4 & 85.5 & 91.2 & 83.1 & 95.7 & 85.7 \\
\hline & Oven-dry & 91.4 & 90.2 & 90.6 & 85.9 & 91.0 & 84.8 & 89.4 & 82.6 & 89.9 & 82.3 \\
\hline & SEM & 1.0 & 0.8 & 0.5 & 0.8 & 0.5 & 1.3 & 1.1 & 0.9 & 0.8 & 1.0 \\
\hline & $p$-value & NS & NS & NS & NS & NS & NS & NS & NS & $* *$ & * \\
\hline \multirow[t]{4}{*}{ ATTD of CP } & Freeze-dry & 90.9 & 89.6 & 90.3 & 87.6 & 91.3 & 86.2 & 85.8 & 84.3 & 90.4 & 83.4 \\
\hline & Oven-dry & 90.8 & 90.1 & 89.4 & 87.8 & 91.3 & 85.2 & 84.4 & 84.1 & 89.9 & 82.9 \\
\hline & SEM & 1.1 & 0.9 & 0.3 & 0.6 & 0.6 & 0.8 & 1.5 & 1.0 & 0.7 & 0.9 \\
\hline & p-value & NS & NS & NS & NS & NS & NS & NS & NS & NS & NS \\
\hline
\end{tabular}

SEM, standard error of means; NS, non-significant.

1) Data were get by using total feces collection method.

${ }^{*} p<0.05,{ }^{* *} p<0.01$.

on poultry also reported no significant differences between the FD and OD techniques on chicken excreta samples in determining the true ME value of poultry diet [17]. However, Wallis and Balnave [29] reported greater energy and $\mathrm{N}$ losses when excreta were freeze-dried rather than being oven-dried at $60^{\circ} \mathrm{C}$ or $80^{\circ} \mathrm{C}$. Those results were somehow in accordance with ours, since we had numerical greater DE and ME estimations in almost all the test diets when the FD technique was used, although not significant difference, indicating less fecal energy loss using the OD technique. The current results of no significant effects of drying method on the ATTD of CP in diets was in agreement with those of Jorgensen et al [30], who reported that the two drying techniques (FD vs OD at $70^{\circ} \mathrm{C}$ ) of feces did not affect measurement of protein digestibility. Therefore, the greater DE concentration and ATTD of GE in feeds calculated with FD technique may be not caused by greater nitrogen loss. Based on the above analysis, the OD technique is more recommended considering its lower fecal energy loss and lower cost compared with the FD technique when drying fecal samples.

Methodology effects on determining energy concentration and nutrient digestibility in feed ingredients

Greater DE, ME, ME/DE ratio, and ATTD of GE in corn were observed when evaluated based on F2 formulation compared with the F1 formulation ( $\mathrm{p}<0.05$, Table 8$)$. When determining the energy concentration and nutrient digestibility of corn, method based on F2 formulation actually belongs to the direct method, while method based on F1 formulation belongs to indirect method. The influence of interaction between the basal diet and test ingredient was smaller for the direct method compared with the indirect method, resulting in greater energy values of corn evaluated based on F2. The DE values of WB, SBM or RSM, and the ME values of SBM or RSM evaluated based on F1 were greater than those determined based on F2 ( $\mathrm{p}<0.05)$. These findings were contradict with previous studies which compared the effects of different basal diets on determined digestibility coefficients of ingredients and found no differences [6-8]. However, the current findings confirmed that constituent of basal diets could affect the estimated DE and $\mathrm{ME}$ values of test ingredients. When determining the energy concentration of ingredients rich in fibre or protein, such as WB, SBM, and RSM, the corn basal diet may have too simple composition, just as that included in F2. The LPB diet in the F1 formulation was more complicated and already contained a portion of the tested ingredients, e.g. SBM and RSM, leading to the real substitution rate of these two feedstuffs to be greater than $30 \%$. This may partial explain the 
Table 8. The digestible energy (DE), metabolizable energy (ME), and the apparent total tract digestibility (ATTD) of gross energy (GE) in experimental diets fed to growing pigs (\% as fed basis) $)^{1)}$

\begin{tabular}{|c|c|c|c|c|c|}
\hline Item & Method & Corn & Wheat bran & Soybean meal & Rapeseed meal \\
\hline \multirow[t]{9}{*}{$\mathrm{DE}(\mathrm{MJ} / \mathrm{kg})$} & Formulation 1 & 13.66 & 12.11 & 15.72 & 12.48 \\
\hline & Formulation 2 & 14.55 & 11.42 & 14.52 & 11.51 \\
\hline & SEM & 0.09 & 0.22 & 0.16 & 0.22 \\
\hline & p-value & $* * *$ & * & *** & ** \\
\hline & Total feces collection method & 14.04 & 11.48 & $15.26^{\mathrm{ab}}$ & 12.05 \\
\hline & Acid-insoluble ash marker method & 13.98 & 11.88 & $15.53^{\mathrm{a}}$ & 11.88 \\
\hline & $\mathrm{Cr}_{2} \mathrm{O}_{3}$ marker method & 14.10 & 12.14 & $14.82^{b}$ & 12.26 \\
\hline & SEM & 0.11 & 0.27 & 0.19 & 0.26 \\
\hline & $p$-value & NS & NS & * & NS \\
\hline \multirow[t]{9}{*}{$\mathrm{ME}(\mathrm{MJ} / \mathrm{kg})$} & Formulation 1 & 13.20 & 11.84 & 15.35 & 11.98 \\
\hline & Formulation 2 & 14.36 & 11.28 & 14.22 & 11.34 \\
\hline & SEM & 0.12 & 0.27 & 0.19 & 0.22 \\
\hline & $p$-value & $* * *$ & NS & $* * *$ & * \\
\hline & Total feces collection method & 13.70 & 11.24 & 14.92 & 11.73 \\
\hline & Acid-insoluble ash marker method & 13.64 & 11.66 & 15.19 & 11.56 \\
\hline & $\mathrm{Cr}_{2} \mathrm{O}_{3}$ marker method & 13.76 & 11.94 & 14.48 & 11.83 \\
\hline & SEM & 0.15 & 0.32 & 0.24 & 0.27 \\
\hline & p-value & NS & NS & NS & NS \\
\hline \multirow[t]{9}{*}{$M E: D E$} & Formulation 1 & 96.6 & 95.8 & 96.6 & 98.3 \\
\hline & Formulation 2 & 98.7 & 96.5 & 97.1 & 95.3 \\
\hline & SEM & 0.4 & 0.7 & 0.5 & 0.9 \\
\hline & p-value & $* * *$ & NS & NS & * \\
\hline & Total feces collection method & 97.5 & 96.0 & 96.8 & 96.4 \\
\hline & Acid-insoluble ash marker method & 97.5 & 96.2 & 96.9 & 96.4 \\
\hline & $\mathrm{Cr}_{2} \mathrm{O}_{3}$ marker method & 97.5 & 95.9 & 96.7 & 96.1 \\
\hline & SEM & 0.5 & 0.9 & 0.6 & 1.0 \\
\hline & $p$-value & NS & NS & NS & NS \\
\hline \multirow[t]{9}{*}{ ATTD of GE } & Formulation 1 & 89.1 & 70.7 & 92.1 & 72.7 \\
\hline & Formulation 2 & 93.8 & 68.8 & 91.0 & 66.6 \\
\hline & SEM & 0.6 & 1.4 & 1.0 & 1.4 \\
\hline & $p$-value & $* * *$ & NS & NS & ** \\
\hline & Total feces collection method & 91.1 & 68.8 & $92.0^{\mathrm{ab}}$ & 70.1 \\
\hline & Acid-insoluble ash marker method & 90.7 & 69.8 & $93.6^{a}$ & 68.1 \\
\hline & $\mathrm{Cr}_{2} \mathrm{O}_{3}$ marker method & 91.5 & 71.3 & $89.2^{b}$ & 72.2 \\
\hline & SEM & 0.7 & 1.6 & 1.2 & 1.7 \\
\hline & $p$-value & NS & NS & * & NS \\
\hline
\end{tabular}

SEM, standard error of means; NS, non-significant.

1) The interaction effects were not significiant in all ingredients, thus only the main effects were shown in the current table.

${ }^{a-b}$ Means with different superscripts in each column differ significantly $(p<0.05)$; Means are the least square means $(n=14)$.

${ }^{*} p<0.05,{ }^{* *} p<0.01,{ }^{* * *} p<0.001$.

greater DE or ME values of SBM and RSM evaluated using F1 formulation, since a higher inclusion level of test ingredient will lead to more accuracy and greater estimation of energy concentration in the difference method [5]. Furthermore, the lower DE or ME values of WB or RSM evaluated based on F2 may be due to the decreased energy contents of the test diets in the present of fibrous ingredients. It was shown that increased dietary fibre level would decrease the ATTD of DM and GE in diets [31,32], leading to less discrepancy of energy contents between test diet and basal diet in the difference method [5]. The greater DE or ME values of SBM determined based on $\mathrm{F} 1$ can be explained by the greater $\mathrm{DE}$ or $\mathrm{ME}$ values of the SBM test diet, which were caused by $4.0 \%$ more CP in SBM test diet formulated by F1. The concentration of DE and ATTD of GE in SBM determined using the AIA marker method were greater than those determined by the $\mathrm{Cr}_{2} \mathrm{O}_{3}$ marker method ( $\mathrm{p}<0.05)$, regardless of the formulations ( $\mathrm{F} 1$ or $\mathrm{F} 2$ ). Overall, the interaction between the energy concentration and digestibility values of components in the test ingredient and the basal diet exists. The formulation procedure can affect the evaluation results of the energy content and nutrient digestibility of feedstuffs, but it depends on the characteristics 
of the test ingredients.

\section{CONCLUSION}

The AIA naturally contained in feed can be a reliable internal marker used for nutrient digestibility calculations. Chromic oxide as an external marker showed or tended to show greater estimated values on energy concentration and nutrient digestibility compared with the AIA marker method or the TC method, respectively. Oven drying technique lost less energy on drying fecal samples compared with freeze drying technique. The constituent of basal diets can influence the results when using the difference method to evaluate feedstuffs. In summary, the AIA marker method or the TC method combined with oven drying of feces is recommended on determining the energy concentration and nutrient digestibility of components in diets fed to growing pigs. Moreover, the complicated basal diet formulation used in Europe may be more accurate on determining the energy concentration of fibre or protein-rich ingredients fed to growing pigs.

\section{CONFLICT OF INTEREST}

We certify that there is no conflict of interest with any financial organization regarding the material discussed in the manuscript. Jaworski NW is an employee of Trouw Nutrition.

\section{ACKNOWLEDGMENTS}

This research was financially supported by the NUTRECO Company, Stationsstraat 77, Amersfoort, Netherlands.

\section{REFERENCES}

1. Adeola O, Bajjalieh NL. Energy concentration of high-oil corn varieties for pigs. J Anim Sci 1997;75:430-6.

2. Pedersen C, Boersma MG, Stein HH. Energy and nutrient digestibility in NutriDense corn and other cereal grains fed to growing pigs. J Anim Sci 2007;85:2473-83.

3. Pan L, Li P, Ma XK, et al. Tannin is a key factor in the determination and prediction of energy content in sorghum grains fed to growing pigs. J Anim Sci 2016;94:2879-89.

4. Young LG, Ashton GC, Smith GC. Estimating the energy value of some feeds for pigs using regression equations. J Anim Sci 1977;44:765-71.

5. Kong C, Adeola O. Invited review: Evaluation of amino acid and energy utilization in feedstuff for swine and poultry diets. Asian-Australas J Anim Sci 2014;27:917-25.

6. May RW, Bell JM. Digestible and metabolizable energy values of some feeds for the growing pigs. Can J Anim Sci 1971;51: 271-8.

7. Widyaratne GP, Zijlstra RT. Nutritional value of wheat and corn distiller's dried grain with solubles: Digestibility and digestible contents of energy, amino acids and phosphorus, nutrient excretion and growth performance of grower-finisher pigs. Can J Anim Sci 2007;87:103-14.

8. Li YS, Tran H, Bundy JW, Burkey TE, Kerr BJ, Nielsen MK, Miller PS. Evaluation of collection method and diet effects on apparent digestibility and energy values of swine diets. J Anim Sci 2016;94:2415-24.

9. Agudelo JH, Lindemann MD, Cromwell GL. A comparison of two methods to assess nutrient digestibility in pigs. Livest Sci 2010;133:74-7.

10. Bakker GCM, Jongbloed AW. The effect of housing system on apparent digestibility in pigs, using the classical and marker (chromic oxide, acid-insoluble ash) techniques, in relation to dietary composition. J Sci Food Agric 1994;64:107-15.

11. Kavanagh S, Lynch PB, O’Mara F, Caffrey PJ. A comparison of total collection and marker technique for the measurement of apparent digestibility of diets for growing pigs. Anim Feed Sci Technol 2001;89:49-58.

12. Hodgkinson SM, Schmidt M, Ulloa N. Comparison of the digestible energy content of maize, oats and alfalfa between the European wild boar (Sus scrofa L.) and Landrace $\times$ Large White pig (Sus scrofa domesticus). Anim Feed Sci Technol 2008; 144:167-73.

13. McCarthy JF, Aherne FX, Okai DB. Use of $\mathrm{HCl}$ insoluble ash as an index material for determining apparent digestibility with pigs. Can J Anim Sci 1974;54:107-9.

14. Fahey GCJ, Jung HG. Lignin as a marker in digestion studies: a review. J Anim Sci 1983;57: 220-5.

15. Bolarinwa OA, Adeola O. Regression and direct methods do not give different estimates of digestible and metabolizable energy values of barley, sorghum, and wheat for pigs. J Anim Sci 2016;94:610-8.

16. Jacobs BM, Patience JF, Dozier WA, Stalder KJ, Kerr BJ. Effects of drying methods on nitrogen and energy concentrations in pig feces and urine, and poultry excreta. J Anim Sci 2011;89: 2624-30.

17. Dale NM, Fuller HL, Pesti GM. Freeze drying versus oven drying of excreta in true metabolizable energy, nitrogen-corrected true metabolizable energy, and true amino acid availability bioassays. Poult Sci 1985;64:362-5.

18. NRC. Nutrient requirements of swine, 11th reved. Washington, DC: National Academy Press; 2012.

19. AOAC. Official methods of analysis, 18th reved. Arlington, VA: Association of Official Analytical Chemists; 2006.

20. Thiex NJ, Anderson S, Gildemeister B. Crude fat, diethyl ether extraction, in feed, cereal grains, and forage (Randall/Soxtec/ Submersion method): Collaborative study. J AOAC Int 2003; 86:888-98.

21. Van Soest PJ, Robertson JB, Lewis BA. Methods for dietary fibre, neutral detergent fibre, and non-starch polysaccharides in relation to animal nutrition. J Dairy Sci 1991;74:3583-97. 
22. Zhang L, Li YK, Li ZC, Li QF, Lyu MB, Li DF, Lai CH. The nutritive values in different varieties of corn planted in one location fed to growing pigs over three consecutive years. AsianAustralas J Anim Sci 2016;29:1768-73.

23. Chen YF, Wu F, Li PL, et al. Energy content and amino acid digestibility of flaxseed expellers fed to growing pigs. J Anim Sci 2016;94:5295-307.

24. Atkinson JL, Hilton JW, Slinger SJ. Evaluation of acid-insoluble ash as an indicator of feed digestibility in rainbow trout (Salmo gairdneri). Can J Fish Aquat Sci 1984;46:1384-6.

25. Jagger S, Wiseman J, Cole DJA, Craigon J. Evaluation of inert markers for the determination of ileal and faecal apparent digestibility values in the pig. Br J Nutr 1992;68:729-39.

26. Yin YL, McEvoy JDG, Schulze H, McCracken KJ. Studies on cannulation method and alternative indigestible markers and the effects of food enzyme supplementation in barley-based diets on ileal and overall apparent digestibility in growing pigs. Anim Sci 2000;70:63-72.

27. Noblet J. Digestive and metabolic utilization of feed energy in swine: Application to energy evaluation systems. J Appl Anim Res 2000;17:113-32.

28. Wunsche J, Borgmann E, Souffrant S, Henning U, Souffrant $\mathrm{U}$. Assessment of nutrient digestibility and energetic feed value of diets for growing-finishing pigs on farm conditions using HCl-insoluble ash as marker. Arch Tierz 1991; 34:561-7.

29. Wallis I, Balnave D. A comparison of different drying techniques for energy and amino acid analyses of poultry excreta. Br Poult Sci 1983;24:255-60.

30. Jorgensen H, Sauer WC, Thacker PA. Amino acid availabilities in soybean meal, sunflower meal, fish meal and meat and bone meal fed to growing pigs. J Anim Sci 1984;58:926-34.

31. Wilfart A, Montagne L, Simmins PH, Van Milgen J, Noblet J. Sites of nutrient digestion in growing pigs: Effect of dietary fibre. J Anim Sci 2007;85:976-83.

32. Urriola PE, Stein HH. Comparative digestibility of energy and nutrients in fibrous feed ingredients fed to Meishan and Yorkshire pigs. J Anim Sci 2012;90:802-12. 